\title{
Study Regarding Research and Development Activity in Korea: Centered on R\&D Performance Rate
}

\author{
Seung-Hwan Jang1)
}

\begin{abstract}
Today's global world economy is based on the knowledge-based society where knowledge and information determine the competitiveness of the country and we have entered the age of limitless competition where the company cannot survive if it cannot secure the market advantage. To respond to such changes in the economic environment, all companies are seeking to lead innovation to create new value one step ahead of its competing companies and are immersing itself in research and development R\&D activity to achieve this. Because of this, companies are continuously increasing investment scale into R\&D activity. What is the reason for the company to increase investment into R\&D activity? From the company's perspective, R\&D investment becomes the driver for stable growth by securing future technology and market competitiveness and such strategic investment can be seen as the core source to create future company value and intangible asset value. In other words, the company is increasing the expenditure related to future economic benefits such as R\&D to gain a strategic advantage in the intensely competitive environment. A relatively early study which performed empirical testing on the effect of expenditure of R\&D expenses on the company's value was the study by Hirschey[1]. Study results observed that R\&D expenses, by expensing entire amount of the R\&D expenses, had a positive $(+)$ effect on the company's market value and, afterward, there were many studies showing empirical testing results on the positive $(+)$ effect on market value, company value, etc. According to such study results, it was confirmed as a definite fact that the expenditure of R\&D expenses, regardless of accounting whether to treat $R \& D$ investment as asset or expense, is a major factor in positively $(+)$ affecting the company's business performance, future economic benefit, or the company's value. Starting from such problem awareness, this study empirically checked R\&D activity rate of Korea's manufacturing companies regarding $R \& D$ activity that has high chance of contributing to the value creation in the future rather than the present and sought to propose $R \& D$ activity direction. This study result is expected to be utilized by the company manager in developing plan for R\&D activity type suitable for development stage of the individual company.
\end{abstract}

Keywords : Research, Development, Activity, R\&D, Performance, Rate

\section{Introduction}

Korea's small to mid-sized companies serve an important role in the Korean economy for job creation, production activity, etc. Due to the advancement of the industrial structure, the role of the small to mid-sized companies is greatly growing in the manufacturing industry and has

Received(September 16, 2019), Review Result(1st: October 5, 2019, 2nd: November 15, 2019), Accepted(January 30, 2020)

1) (Assiatant Professor) 21417 HRD, Korea Polytechnics, Munemi-ro, Bupyeong-gu, Incheon, Korea email: jangsh@kopo.ac.kr 
become an important source that is indispensable in economic progress. Also, according to the entry into the 21st century knowledge-based economy, role of the technology innovation small to mid-sized companies is more important than the large company and it is forecasted that small to mid-sized companies creating new customer value through creative idea and technology innovation have possibility of sustainable development and progress.

But as many products in the business area of small to mid-sized companies are entering maturity in the product development and technology phases, competition between companies are becoming intense, creation of added value is becoming poor, and it is becoming more difficult to improve the company's profit within the limited market size. Also, due to the demand for reduction of product unit price by the existing customer including large company, small to mid-sized companies are faced with more desperate situation to overcome such difficult business environment through internal innovation.

To overcome this new industrial environment, the importance of $R \& D$ activity is increasing more as a method to respond to the modern business environment where intense competition and uncertainty are growing. It is necessary to secure competitiveness based on differentiated technology to secure sustainable growth and profit in the rapidly changing environment.

The company has to continuously create new growth driver through technology innovation or efforts for business innovation. Within R\&D activity, rather than R\&D activity for following market demand increasing in the existing growth period market, it seems that $R \& D$ activity to secure the company's sustainable growth by maintaining continuous relationship with the customer in the mature market is necessary. In particular, customers' increasing interest regarding the company's social responsibility and the environment is demanding the companies to use more of the companies' resources and efforts to be concentrated on such social responsibility and the environment. $R \& D$ activity in the company has to be reviewed and executed to meet such needs of the time.

The United States recognized the importance of the intellectual property earlier than Korea and increased investment in R\&D. The portion of intangible asset making up the assets comprising the market value of the US S\&P 500 companies has rapidly increased from $32 \%$ in 1985 to $80 \%$ in 2010 and the portion of intellectual property making up such intangible asset greatly increased from $10 \%$ in 1985 to $40 \%$ in 2005 . This shows the importance of R\&D activity to secure intellectual property and Korea's government agency and private sector are also concentrating on creating result through strategy $R \& D$ activity to improve global competitiveness. 


\section{Importance of R\&D Activity}

$R \& D$ activity is research performed with the purpose of discovering previously unknown, new scientific principle regarding some fact or phenomenon and means basic research for most basic, pure science and original research for the progress of scientific knowledge without specific, immediate commercial purpose. Applied research develops new scientific knowledge to achieve specific, commercial purpose related to product, process, and service or uses knowledge obtained from the result of basic research to apply certain material, processing process, or processing method for commercialization while development research can be categorized and defined as activity to produce useful material, device, system, or method including prototype and design and development of process using scientific knowledge derived from research result [2].

R\&D activity extended across a wide range of different complex tasks Zuniga-Vicente et al.[3] and $R \& D$ investment is traditionally divided into two factors of research and development[4]. In here, research is mainly related to technical, scientific progress while development converts achieved technical, scientific progress into special product or process innovation. Therefore, $R \& D$ activity always precedes development activity. In existing other studies, research project is conceptualized as "project far from the market" but, on the other hand, development project means "project close to the market"[5].

According to Zuniga-Vicente et al.[3], research activity and development activity are very different from each other regarding performance and forecast according to its activity result. In particular, research can be seen as having larger ambiguity that cannot be perceived and uncertainty compared to development. Also, the company's research activity emphasizes stimulus of absorbing capacity which is a major intangible factor in improving the company's competitive advantage[6]. Also, research investment is shown to increase the possibility of securing a patent compared to development investment[7]. Due to such characteristic, development project always obtains many types of output within less uncertainty compared to research projects. Nixon[8] stated that as R\&D expense increases and the company's technology dependency for competitive advantage increases, external investor and internal managers seek to better measure productivity and effectiveness of $R \& D$ activity. However, the most difficult point in evaluating R\&D performance is that $R \& D$ is one of many activities for successful product development. Despite practical difficulty and limitation in evaluating R\&D performance, financial evaluation method supports realizing communication and agreement and evaluating 
project performance to the decision-makers. Also, Klette \& Griliches[9] stated that R\&D activity induces innovation to create new knowledge or information and innovation leads to new product development or process innovation which as a result becomes an important factor in enhancing the company's value.

Griliches[10] studied changes in R\&D activity and production output from industrial level and claimed that $R \& D$ activity only explains one part of growth rate for total industrial production output with no significant correlation but revealed that total industrial production output can be explained by $R \& D$ activity in a follow-up study utilizing expanded data[11]. Barney[12] emphasized that the company has to possess resource which is irreplaceable, impossible to imitate, scarce, and valuable to retain continuous competitive advantage. Therefore, in the modern society where technology gap between companies becomes relatively, easily narrower due to the progress of technology, the importance of R\&D activity to create core competency is much greater. In other words, it can be understood that the industry sector achieving continuous innovation adjusting to changes required by the external environment through R\&D activity maintains sustainability but the industry sector failing to do so will face threat to its survivability.

Also, R\&D activity not only increases survival possibility and performance of the industry and company but also has a positive effect on improving absorbing capacity to become an important factor in achieving future innovation[13]. Absorbing capacity means the ability to integrate current assets and perceiving and absorbing external, valuable knowledge[14]. Although performance through the company's R\&D activity is uncertain and difficult to achieve in a short period, absorbing capacity accumulated through R\&D activity performs the role of catalyst for innovation and it was revealed that it makes it possible to achieve continuous innovation through absorption and integration of external resources and application process[15]. Such R\&D activity not only has a very important role in the company's continued existence and progress but also can be seen as a decisive factor in determining the future's country economy.

\section{R\&D Activity and Business Performance}

Business performance can be shown as financial performance and non-financial performance gained by the company through company activity with main financial performance indexes including sales, net profit, etc. and non-financial performance indexes including market share, brand value, customer perception, etc. Although many indexes are used to measure business 
performance, most generally used ones are sales increase, net profit increase, and cash flow and when market is slumping or in depression, product market share and operating profit rate are mainly used to determine business performance. Various empirical studies until now analyzed the company's R\&D activity as important factor in bringing business performance and many small and mid-sized companies are making large investments in R\&D activity for the company's business performance.

Even though R\&D activity has a positive effect on the company's future profit and market value[16], $R \& D$ activity may bring change to the company's performance at an impossible to predict level as the activity period is long and the result is uncertain[17]. Therefore, how to do $R \& D$ activity is a very important decision-making for the company. The company's active $R \& D$ activity has a positive effect on the company's performance. As a result of studying the effect of $R \& D$ on financial (economic) sustainability through marketing performance, operating profit, and technical performance, Dave et al.[18] explained that there is a strong indirect positive $(+)$ relationship between $\mathrm{R} \& \mathrm{D}$ and financial (economic) sustainability through measured operating profit.

Chauvin and Hirschey[19] revealed that R\&D expense and advertising expense had a positive effect on the company's market value by studying top 20 companies in R\&D expenditure from 1988 to 1990 and, in particular, R\&D expense had the most effect on large company's market value while $R \& D$ expense and advertising expense had a relationship with more effect on small specialized companies by industry. Nunes et al.[20] also stated that R\&D activity had a positive effect on the company's growth in small to mid-sized companies and that company size (sales), company history, cash flow, and debt ratio increased profitability. But the company's R\&D activity does not always have a positive effect on performance. $R \& D$ investment may not bring performance as much as input and there is large time uncertainty so companies have a tendency to concentrate more on activity which was successful in the past while reducing $R \& D$ activity to explore new technology[13]. Chan et al.[21] studied the relationship between $R \& D$ expenditure size and stock price at the industry level and it was found that the influence of $R \& D$ expenditure size was different according to the industry. Specifically, in the case of high-technology firms, stock price increased at a greater than average level after announcing to expand R\&D expenditure size while in the case of low-technology firms, stock price was found to drop at a less than average level. In other words, it was found that R\&D concentration level greater than industry's average R\&D concentration level had a positive effect on the stock price only in high-technology industries. 


\section{Korea's R\&D Activity Rate Status}

For Korea's R\&D activity rate status investigation, Korean Innovation Survey (manufacturing industry sector) data published by Korea's Science \& Technology Policy Institute was utilized. Corresponding data has the purpose of identifying the status and characteristics of the overall innovation activity of Korea's manufacturing industry and securing and providing basic data required innovative research and developing a national innovation policy. As nearly the only investigation on innovation activity at company level being performed currently in Korea, it is an important and essential statistical study[22]. Korean Innovation Survey is performed every 2 years and comparative analysis was executed by utilizing recent 2018[22], 2016[23], and 2014[24] survey data.

2018 survey sampled 3,500 manufacturing companies from population (51,553 companies) created by integrating business list and company population from the nationwide business survey from Statistics Korea composed in 2016. Companies with more than 500 full-time employees were in the complete enumeration group so whole list in the population was entirely sampled and systematic sampling (Method to sample at equidistant intervals. If population is 100 and sample size is 10, sample selected at intervals of 10) method was applied within the same industry/size for the other group to become probability sampling (=random sampling)[22].

$R \& D$ activity is classified into three types. First is internal R\&D which means official R\&D activity performed inside the company to produce new knowledge or solve scientific problem. Second is external $R \& D$ which means $R \& D$ activity performed in outsourcing form with another company or agency (public or private lab) with the same purpose as internal R\&D. Third is joint R\&D which means R\&D activity performed jointly through contract between the company's internal research organization and another company or agency with the same purpose as internal $R \& D$. If one of the three types of R\&D activity were performed, it is seen as a company performing R\&D activity.

Only companies performing innovation activity responded to R\&D activity in the survey but our study presented weighted index calculated in comparison to all companies to identify comprehensive data regarding all companies[22].

[Fig. 1] shows the weight of companies performing R\&D activity from all companies with 2018 survey showing R\&D activity rate as 30.9\%, 2016 survey showing 35.9\%, and 2014 survey showing $22.3 \%$. 


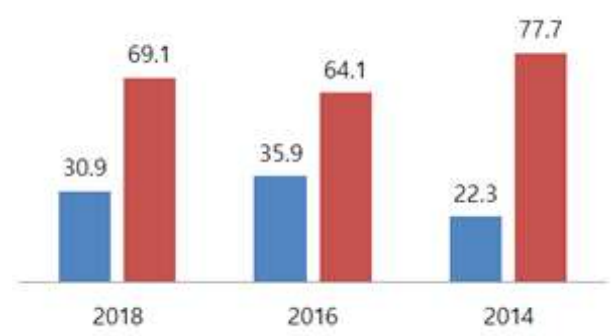

[Fig. 1] R\&D Activity Rate (Unit : \%)

R\&D activity rate by industry is as [Table 1]. In the 2018 survey, R\&D activity rate for electrical equipment industry showed the highest level at $51.1 \%$ and leather, miscellaneous goods, food, medical/precision, etc. areas were also over $40 \%$ which was a relatively high level. Meanwhile, R\&D activity rate of primary metal, beverages, etc. industries was around $10 \%$ showing the lowest activity rate level. In the 2016 survey, R\&D activity rate for pharmaceutical industry showed the highest level at $68.2 \%$ and mechanical equipment, medical/precision, beverages, electronics/computer, chemical, automobile, etc. areas were relatively high level. Meanwhile, R\&D activity rate of printing/recording media, clothing, furniture, etc. industries was around $10 \%$ showing a low level. In the 2014 study, R\&D activity rate for pharmaceutical industry showed the highest level at $61.1 \%$ and chemical $(44.3 \%)$, electronics/computer (42.0\%), etc. areas were relatively high level. Meanwhile, R\&D activity rate of clothing industry was $3.4 \%$ showing the lowest level.

[Table 1] R\&D Activity Rate (by industry) (Unit : \%)

\begin{tabular}{|c|c|c|c|c|c|c|c|c|}
\hline Category & Overall & Food & Beverage & Textile & Clothing & $\begin{array}{c}\text { Leather/ } \\
\text { Misc. Good }\end{array}$ & $\begin{array}{c}\text { Lumber/ } \\
\text { Tree }\end{array}$ & Paper \\
\hline 2018 Survey & 30.9 & 44.1 & 3.2 & 15.0 & 24.4 & 46.8 & 30.2 & 18.4 \\
\hline 2016 Survey & 35.9 & 39.4 & 51.3 & 19.0 & 11.8 & 27.2 & 23.7 & 18.6 \\
\hline 2014 Survey & 22.3 & 26.7 & 16.4 & 11.5 & 3.4 & 20.9 & 10.8 & 9.1 \\
\hline
\end{tabular}

\begin{tabular}{|c|c|c|c|c|c|c|c|c|}
\hline Category & $\begin{array}{c}\text { Printing/ } \\
\text { Recording } \\
\text { Media }\end{array}$ & $\begin{array}{c}\text { Oil } \\
\text { Refining }\end{array}$ & $\begin{array}{c}\text { Chem } \\
\text { ical }\end{array}$ & $\begin{array}{c}\text { Pharmac } \\
\text { eutical }\end{array}$ & $\begin{array}{c}\text { Rubber } \\
/ \\
\text { Plastic }\end{array}$ & $\begin{array}{c}\text { Non- } \\
\text { Metal } \\
\text { Mineral }\end{array}$ & $\begin{array}{c}\text { Primary } \\
\text { Metal }\end{array}$ & $\begin{array}{c}\text { Metal } \\
\text { Processing }\end{array}$ \\
\hline 2018 Survey & 26.1 & 22.4 & 37.5 & 32.1 & 37.2 & 23.2 & 14.2 & 18.9 \\
\hline 2016 Survey & 7.0 & 36.5 & 44.9 & 68.2 & 38.3 & 21.3 & 31.9 & 22.8 \\
\hline 2014 Survey & 9.9 & 14.9 & 44.3 & 61.1 & 24.7 & 15.2 & 8.5 & 17.4 \\
\hline
\end{tabular}

\begin{tabular}{|c|c|c|c|c|c|c|c|c|}
\hline Category & $\begin{array}{c}\text { Electronics } \\
/\end{array}$ & $\begin{array}{c}\text { Medical/ } \\
\text { Computer }\end{array}$ & $\begin{array}{c}\text { Electrical } \\
\text { Equip } \\
\text { ment }\end{array}$ & $\begin{array}{c}\text { Other } \\
\text { Mechanical } \\
\text { Equipment }\end{array}$ & $\begin{array}{c}\text { Auto } \\
\text { mobile }\end{array}$ & $\begin{array}{c}\text { Other } \\
\text { Transport } \\
\text { Equipment }\end{array}$ & $\begin{array}{c}\text { Furn } \\
\text { iture }\end{array}$ & $\begin{array}{c}\text { Other } \\
\text { Product }\end{array}$ \\
\hline
\end{tabular}




\begin{tabular}{|l|l|l|l|l|l|l|l|l|}
\hline 2018 Survey & 38.6 & 44.0 & 51.1 & 34.9 & 33.3 & 21.6 & 17.9 & 14.9 \\
\hline 2016 Survey & 48.6 & 51.5 & 43.5 & 54.8 & 45.0 & 12.8 & 12.4 & 21.3 \\
\hline 2014 Survey & 42.0 & 37.0 & 33.0 & 22.1 & 18.8 & 6.9 & 13.6 & 13.7 \\
\hline
\end{tabular}

[Fig. 2] shows the weight of each R\&D type. From all companies in the 2018 survey, 30.0\% of the companies performed internal $R \& D, 7.8 \%$ performed joint $R \& D$, and $7.6 \%$ performed external R\&D. From all companies in the 2016 survey, 35.0\% of the companies performed internal $R \& D, 5.1 \%$ performed joint $R \& D$, and $1.9 \%$ performed external R\&D. From all companies in the 2014 survey, 20.7\% of the companies performed internal R\&D, 6.7\% performed joint R\&D, and $3.6 \%$ performed external R\&D.

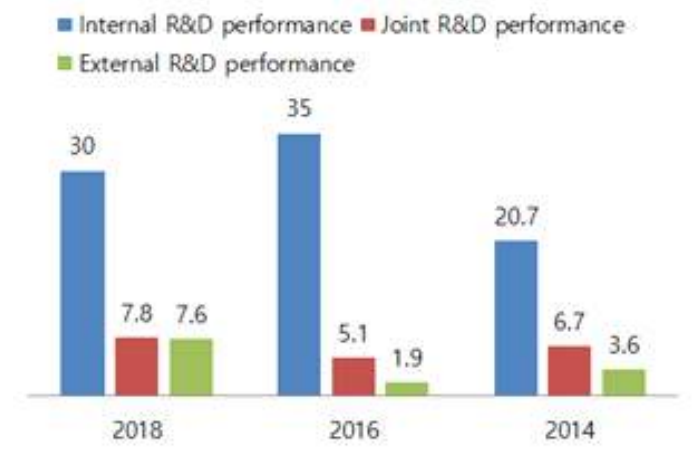

[Fig. 2] Weight by R\&D Type (Multiple Responses) (Unit : \%)

In [Table 2], weight by R\&D type was examined by industry. In the 2018 survey, the order of the industry with the highest internal $R \& D$ performance rate was electrical equipment, leather, miscellaneous goods, medical/precision, and food. Medical/precision area had the highest joint $R \& D$ and external $R \& D$ performance rates so it can be seen that there is an active execution of R\&D activity with various entities in various ways. In the 2016 survey, the order of the industry with the highest internal $R \& D$ performance rate was pharmaceuticals, other mechanical equipment, medical/precision, beverages, and electronics/computer. Beverages and pharmaceutical areas had noticeably high joint $R \& D$ and external $R \& D$ performance rates so it can be seen that there is active execution of $R \& D$ activity with various entities in various ways. In the 2014 survey, industries with the highest internal R\&D performance rate were pharmaceuticals, chemical, and electronics/computer. Also, joint $R \& D$ and external $R \& D$ were shown to be high in pharmaceuticals, chemical, and electronics/computer areas and in the case where overall $R \& D$ performance rate was high, weight by type increases alongside. 
[Table 2] Rate by R\&D Type (multiple responses, by industry) (Unit : \%)

http://dx.doi.org/10.21742/apjcri.2020.02.02

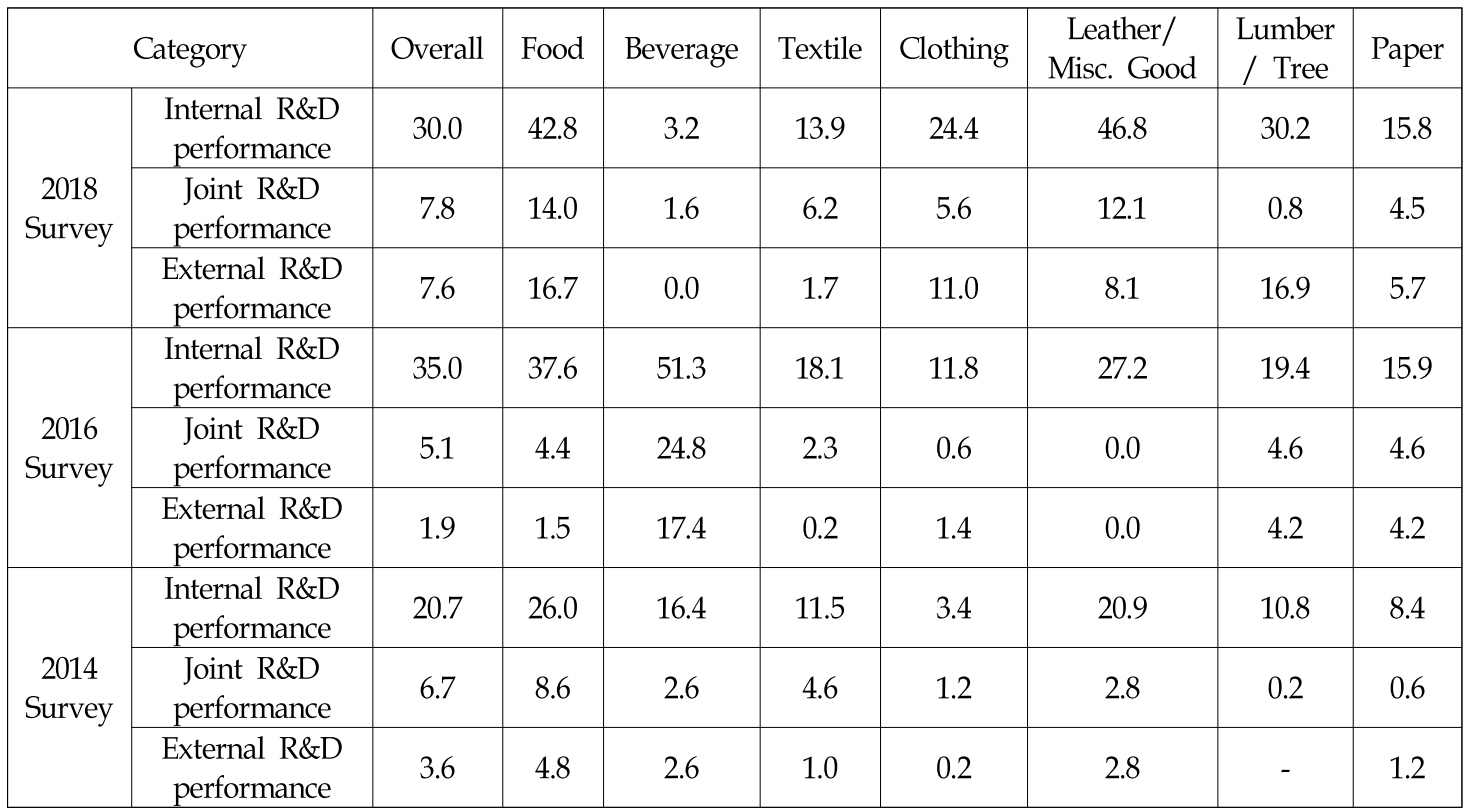

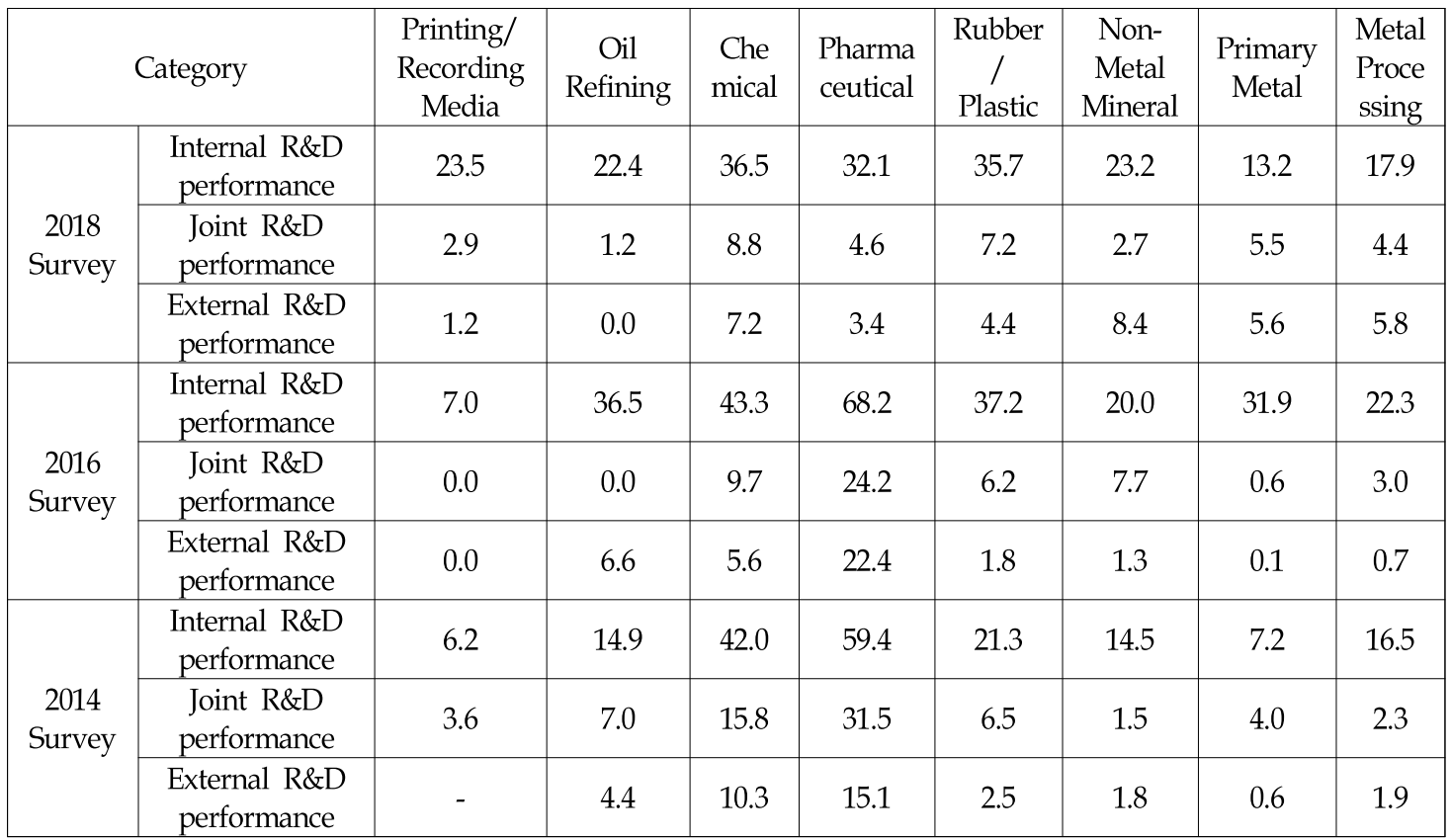

\begin{tabular}{|c|c|c|c|c|c|c|c|c|c|}
\hline \multicolumn{2}{|c|}{ Category } & $\begin{array}{c}\text { Elect } \\
\text { ronics/ } \\
\text { Com } \\
\text { puter }\end{array}$ & $\begin{array}{c}\text { Medical } \\
\text { / }\end{array}$ & $\begin{array}{c}\text { Elect } \\
\text { rical } \\
\text { Equip } \\
\text { ment }\end{array}$ & $\begin{array}{c}\text { Other } \\
\text { Mechanical } \\
\text { Equipment }\end{array}$ & $\begin{array}{c}\text { Auto } \\
\text { mobile }\end{array}$ & $\begin{array}{c}\text { Other } \\
\text { Transport } \\
\text { Equipment }\end{array}$ & $\begin{array}{c}\text { Furn } \\
\text { iture }\end{array}$ & $\begin{array}{c}\text { Other } \\
\text { Pro } \\
\text { duct }\end{array}$ \\
\hline $\begin{array}{c}2018 \\
\text { Sur }\end{array}$ & $\begin{array}{c}\text { Internal R\&D } \\
\text { performance }\end{array}$ & 38.1 & 43.1 & 49.7 & 34.4 & 33.1 & 21.6 & 17.9 & 14.9 \\
\hline
\end{tabular}


Study Regarding Research and Development Activity in Korea: Centered on R\&D Performance Rate

\begin{tabular}{|c|c|c|c|c|c|c|c|c|c|}
\hline \multirow{2}{*}{ vey } & $\begin{array}{c}\text { Joint R\&D } \\
\text { performance }\end{array}$ & 7.7 & 21.0 & 12.1 & 9.9 & 5.9 & 8.8 & 3.1 & 2.9 \\
\cline { 2 - 10 } & $\begin{array}{c}\text { External R\&D } \\
\text { performance }\end{array}$ & 15.1 & 18.9 & 6.7 & 6.8 & 6.7 & 7.0 & 0.0 & 2.9 \\
\hline \multirow{2}{*}{$\begin{array}{c}2016 \\
\text { Sur } \\
\text { vey }\end{array}$} & $\begin{array}{c}\text { Internal R\&D } \\
\text { performance }\end{array}$ & 48.1 & 51.5 & 42.0 & 54.2 & 43.5 & 12.4 & 12.4 & 21.3 \\
\cline { 2 - 10 } & $\begin{array}{c}\text { Joint R\&D } \\
\text { performance }\end{array}$ & 5.3 & 11.9 & 3.0 & 6.6 & 7.4 & 1.5 & 4.1 & 4.5 \\
\hline \multirow{2}{*}{$\begin{array}{c}\text { External R\&D } \\
\text { performance }\end{array}$} & 3.8 & 3.0 & 0.7 & 1.8 & 3.5 & 1.5 & 2.3 & 0.0 \\
\hline $\begin{array}{c}\text { Sur } \\
\text { vey } \\
\text { pernal R\&D }\end{array}$ & $\begin{array}{c}\text { Joint R\&D } \\
\text { performance }\end{array}$ & 19.3 & 12.6 & 9.5 & 5.0 & 7.8 & 2.4 & 2.4 & 4.3 \\
\cline { 2 - 11 } & $\begin{array}{c}\text { External R\&D } \\
\text { performance }\end{array}$ & 11.2 & 3.6 & 5.6 & 2.8 & 5.5 & 1.2 & - & 2.6 \\
\hline
\end{tabular}

Category by size and company type is as [Table 3]. All 2018, 2016, and 2014 surveys showed that, regardless of $\mathrm{R} \& \mathrm{D}$ activity type, performance rate increases overall as number of employees is larger and company type is large company. In particular, if it is large company type, internal $R \& D$ performance rate is high while joint $R \& D$ and external $R \& D$ rates do not make up large portions in all company types based on absolute ratio.

[Table 3] R\&D Type by Size and Company Type (Unit : Person, \%)

\begin{tabular}{|c|c|c|c|c|c|c|c|c|c|c|}
\hline \multirow{2}{*}{\multicolumn{2}{|c|}{ Category }} & \multirow{3}{*}{$\begin{array}{c}\text { Overall } \\
30.1\end{array}$} & \multicolumn{5}{|c|}{ Number of Employees (Person) } & \multicolumn{3}{|c|}{ Company Type (\%) } \\
\hline & & & \multirow{2}{*}{$\begin{array}{c}10 \sim \\
49 \\
27.3\end{array}$} & \multirow{2}{*}{$\begin{array}{c}50 \sim \\
99 \\
36.9\end{array}$} & \multirow{2}{*}{$\begin{array}{l}100 \sim \\
299 \\
53.1\end{array}$} & \multirow{2}{*}{$\begin{array}{c}300 \sim \\
499 \\
58.3\end{array}$} & \multirow{2}{*}{$\begin{array}{c}\text { Over } \\
500 \\
57.2\end{array}$} & \multirow{2}{*}{$\begin{array}{c}\begin{array}{c}\text { Small } \\
\text { company }\end{array} \\
26.0\end{array}$} & \multirow{2}{*}{$\begin{array}{c}\begin{array}{c}\text { Mid-sized } \\
\text { company }\end{array} \\
35.6\end{array}$} & \multirow{2}{*}{$\begin{array}{c}\begin{array}{c}\text { Large } \\
\text { company }\end{array} \\
61.1\end{array}$} \\
\hline \multirow{3}{*}{$\begin{array}{l}2018 \\
\text { Sur } \\
\text { vey }\end{array}$} & $\begin{array}{l}\text { Internal R\&D } \\
\text { performance }\end{array}$ & & & & & & & & & \\
\hline & $\begin{array}{l}\text { Joint R\&D } \\
\text { performance }\end{array}$ & 7.8 & 6.7 & 9.4 & 16.3 & 31.6 & 28.3 & 7.2 & 8.3 & 26.5 \\
\hline & $\begin{array}{l}\text { External R\&D } \\
\text { performance }\end{array}$ & 7.6 & 6.8 & 10.4 & 12.6 & 17.3 & 21.3 & 5.1 & 11.3 & 15.7 \\
\hline \multirow{3}{*}{$\begin{array}{l}2016 \\
\text { Sur } \\
\text { vey }\end{array}$} & $\begin{array}{l}\text { Internal } \mathrm{R} \& \mathrm{D} \\
\text { performance }\end{array}$ & 35.0 & 29.4 & 56.8 & 70.3 & 77.9 & 81.7 & 29.3 & 54.3 & 83.1 \\
\hline & $\begin{array}{l}\text { Joint R\&D } \\
\text { performance }\end{array}$ & 5.1 & 4.5 & 5.9 & 8.7 & 13.0 & 31.5 & 4.1 & 8.1 & 17.3 \\
\hline & $\begin{array}{l}\text { External R\&D } \\
\text { performance }\end{array}$ & 1.9 & 1.7 & 2.5 & 2.7 & 2.8 & 26.4 & 1.5 & 2.9 & 11.8 \\
\hline \multirow{3}{*}{$\begin{array}{l}2014 \\
\text { Sur } \\
\text { vey }\end{array}$} & $\begin{array}{l}\text { Internal } R \& D \\
\text { performance }\end{array}$ & 20.7 & 17.5 & 26.1 & 38.5 & 54.6 & 74.1 & 17.5 & 30.5 & 65.8 \\
\hline & $\begin{array}{l}\text { Joint R\&D } \\
\text { performance }\end{array}$ & 6.7 & 5.1 & 10.0 & 13.4 & 28.0 & 37.6 & 5.2 & 11.1 & 30.8 \\
\hline & $\begin{array}{l}\text { External R\&D } \\
\text { performance }\end{array}$ & 3.6 & 2.9 & 5.0 & 6.5 & 17.3 & 18.8 & 2.8 & 5.8 & 17.0 \\
\hline
\end{tabular}




\section{Implications and Conclusion}

Considering that $\mathrm{R} \& \mathrm{D}$ activity requires certain period of time before performance creation instead of immediately due to its characteristic, large growth is expected in the future for professional/scientific, and technical service industries, broadcast/communication, and IT service industry where R\&D activity is active. Also, even in industry where satisfactory performance is not being obtained, it is determined that future profit can be secured if the importance of $R \& D$ activity is perceived and such investment is expanded. For this, strategic direction is required for achieving innovation from a long-term perspective.

Although Korea achieved rapid growth from the 1990s to the present, in order to break from the current low-growth situation while facing new paradigm such as 4th industrial revolution, it is necessary to create knowledge and technology exchange through external interaction. According to the forecast that fusion/convergence technology will lead the future industrial technology through combination of technologies, each industry must break away from closed R\&D activity focusing on the company's internal resource and capability and change to Open $R \& D$ based on connecting internal and external entities[25]. Also, for successful adoption of Open R\&D, effort is required for systematic implementation of building cooperation between the company and industry.

Many people state that Korea's companies still claim that absolute amount of investment has to be raised rather than calculating efficiency of R\&D expenditure. Of course, considering relatively insufficient $R \& D$ investment than technology level compared to the leading company, claim that absolute level of $\mathrm{R} \& \mathrm{D}$ expenditure has to be higher has sufficient basis. But as technology and resource are lacking, additional investment for R\&D has to be concentrated on projects with high possibility of improving sales and profits.

For R\&D activity with high profit, it is important to newly establish R\&D area's mission to meet the market. In other words, through active cooperation with the marketing, market flow and customer needs have to be actively reflected into R\&D activity and R\&D personnel has to possess entrepreneurial capability to calculate comprehensive investment profit rate from business and market perspectives instead of just performing the research project.

Companies recognize that $R \& D$ is key for company's competitiveness as a driver to maintain competitive advantage and prepare for the future but as uncertainty increases in the process of connecting investment in R\&D activity with the company's profits, there are cases where investment cannot be actively, readily executed. Therefore, this study emphasized that the 
companies need to focus on the strategic approach regarding R\&D activity instead of simply increasing R\&D activity. If future research studies comparison/analysis of foreign industries in addition to Korea's industry, more meaningful proposals can be made to Korean industry's continuous development.

\section{References}

[1] Hirschey, M, Intangible Capital Aspects of Advertising and R\&D Expenditures, Journal of Industrial Economics, (1982), Vol.30, No.4, pp.375-390, https://doi.org/10.2307/2097924.

[2] National Science Board Science and Engineering Indicators 2008, Arlington, VA: National Science Foundation, (2008)

[3] Zuniga-Vicente, J. A., C. Alonso-Borrego, F. J. Forcadell, and J. I. Gal'an, Assessing the effect of public subsidies on firm R\&D investment: A Survey, (2014), Vol.28, No.1, pp.36-67, https://doi.org/10.1111/j.1467-6419.2012.00738.x

[4] Aerts, K. and T. Schmidt, Two for the Price of One? Additionality effects of R\&D subsidies: a comparison between Flanders and Germany, Research Policy, (2008), Vol.37, No.5, pp.806-822, https://doi.org/10.1016/j.respol.2008.01.011.

[5] Clausen, T. H., Do subsidies have positive impacts on R\&D and innovation activities at the firm level?, Structural Change and Economic Dynamics, (2007), Vol.20, No.4, pp.239-253, https://doi.org/10.1016/j.strueco.2009.09.004.

[6] Cockburn, I. M. and R. M. Henderson, Absorptive capacity coauthoring behavior and the organization of research in drug discovery, The Journal of Industrial Economics, (1998), Vol.46, No.2, pp.157-182, https://doi.org/10.1111/1467-6451.00067.

[7] Czarnitzki, D., K. Kraft, and S. Thorwarth, The knowledge production of 'R' and 'D', Economic Letters, (2009), Vol.105, No.1, pp.141-143, https://doi.org/10.1016/j.econlet.2009.06.020.

[8] Nixon, B., Research and development performance measurement: a case study, Management Accounting Research, (1998), Vol.9, No.3, pp.329-355.

[9] Klette, T. J. and Zvi Griliches, Empirical Patterns of Firm Growth and R\&D Investment: A Quality Ladder Model Interpretation, NBER Working Paper, (1998), Vol.110, No.463, pp.363-387, https://doi.org/10.1111/1468-0297.00529.

[10] Griliches, Z., R\&D and the Productivity Slowdown, The American Economic Review, Papers and Proceedings of the Ninety-Second Annual Meeting of the American Economic Association, (1980), Vol.70, No.2, pp. 343-348

[11] Griliches, Z., and Lichtenberg, F. R., R\&D and productivity growth at the industry level: is there still a relationship? R\&D patents and productivity, University of Chicago Press, (1984)

[12] Barney, J. B., Firm Resources and Sustained Competitive Advantage, Journal of Management, (1991), Vol.17, No.1, pp.99-120, https://doi.org/10.1177/014920639101700108. 
[13] Cohen, W. M., and Levinthal, D. A., Innovation and learning: the two faces of R\&D, The Economic Journal, (1989), Vol.99, No.397, pp.569-596, https://doi.org/10.2307/2233763.

[14] Cohen, W. M., and Levinthal, D. A., Absorptive capacity: A new perspective on learning and innovation, Administrative Science Quarterly, (1990), Vol.35, No.1, pp.128-152, https://doi.org/10.2307/2393553.

[15] Griffith, R., Redding, S., and Van Reenen, J., Mapping the two faces of R\&D: Productivity growth in a panel of OECD industries, Review of Economics and Statistics, (2006), Vol.86, No.4, pp.883-895, https://doi.org/10.1162/0034653043125194

[16] Sougiannis, Theodore, The accounting based valuation of corporate R and D, Accounting Review, (1994), Vol.69, No.1, pp.44-68.

[17] Baysinger, Barry D., Rita D. Kosnik, and Thomas A. Turk, Effects of board and ownership structure on corporate R\&D strategy, Academy of Management Journal, (1991), Vol.34, No.1, pp.205-214, https://doi.org/10.2307/256308.

[18] Dave, P., V. Wadhwa, S. Aggarwal, and A. Seetharaman, The Impact of Research and Development on the Financial Sustainability of Information Technology (IT) Companies Listed on the S\&P 500 Index, Journal of Sustainable Development; (2013), Vol.6, No.11, pp.122-138, 10.5539/jsd.v6n11p122.

[19] Chauvin, K. W. and M. Hirschey, Advertising, R\&D Expenditures and the Market Value of the Firm, Financial Management, (1993), Vol.22, No.4, pp.128-140, https://doi.org/10.2307/3665583.

[20] Nunes, P. M., Z. Serrasqueiro, and J. Leitao, Is There a Linear Relationship between R\&D Intensity and Growth? Empirical Evidence of Non-high-tech vs. High-tech SMEs, Research Policy, (2012), Vol.41, No.1, pp.36-53, https://doi.org/10.1016/j.respol.2011.08.011.

[21] Chan, S., Martin, J. \& Kensinger, J,. Corporate Research and Development Expenditures and Share Value, Journal of Financial Economics, (1990), Vol.26, No.2, pp.255-276, https://doi.org/10.1016/0304-405X(90)90005-K.

[22] Science and Technology Policy Institute, Report on 2018 Korean Innovation Survey: Manufacturing Sector, (2018)

[23] Science and Technology Policy Institute, Report on 2016 Korean Innovation Survey: Manufacturing Sector, (2016)

[24] Science and Technology Policy Institute, Report on 2014 Korean Innovation Survey: Manufacturing Sector, (2014)

[25] Korea Meteorological Institut, Industry R\&D Trend (Status of R\&D in meteorological industry), (2013) 